\title{
Протезування висхідного відділу аорти в пацієнта з розшаровуючою аневризмою аорти типу А після аортокоронарного шунтування (клінічний випадок)
}

\author{
Павленко А. В., Варбанець С. В., Довгань О. М., Пукас О. Ю. \\ ДУ «Науково-практичний медичний центр дитячої кардіології та кардіохірургії МОЗ України», м. Київ, Україна
}

\begin{abstract}
Резюме. Розшаровуюча аневризма аорти після кардіохірургічних втручань $є$ рідкісною патологією в пацієнтів після попереднього аортокоронарного шунтування. Така патологія часто супроводжується недостатністю аортального клапана, синдромом мальперфузії нижніх кінцівок та іншими симптомами.

Мета роботи. Представити складний випадок корекції розшаровуючої аневризми аорти типу А, помірною до вираженої аортальної недостатності та синдрому мальперфузії правої нижньої кінцівки в пацієнта з надлишковою масою тіла та після кардіохірургічного втручання.

Матеріали і методи. Пацієнт віком 39 років поступив зі скаргами на підвищення артеріального тиску, біль у правій нижній кінцівці та порушення ії функції. Під час обстеження було діагностовано розшаровуючу аневризму аорти типу А та синдром мальперфузії правої нижньої кінцівки.

Результати та обговорення. Розшаровуюча аневризма аорти типу А в поєднанні з аортальною недостатністю та синдромом мальперфузії нижніх кінцівою є рідкісною патологією в пацієнтів з надлишковою масою тіла та після попередньо проведеного аортокоронарного шунтування в 2015 році. Не було знайдено описань таких випадків у вітчизняній літературі. Проведено протезування аорти з формуванням дистального анастомозу за типом Hemiarch з використанням ретроградної церебральної перфузії та стегново-стегнове шунтування.

Висновок. Протезування висхідного відділу аорти з формуванням дистального анастомозу за типом Hemiarch із ресуспензією аортального клапана з використанням ретроградної церебральної перфузії та глибокої гіпотермії, а також формування стегново-стегнового анастомозу забезпечило хороший результат у пацієнта з розшаровуючою аневризмою аорти, недостатністю аортального клапана, синдромом мальперфузії нижніх кінцівок та з надлишковою масою тіла.
\end{abstract}

Ключові слова: розшаровуюча аневризма аорти типу А, повторне кардіохірургічне втручання, стегново-стегнове шунтування, протезування висхідного відділу аорти.

Вступ. Гостре розшарування аорти - це раптовий дефект внутрішньої оболонки стінки аорти з подальшим проникненням потоку крові в дегенеративно змінений середній шар, утворенням внутрішньостінної гематоми та поздовжнім розшаруванням стінки аорти. Частота виникнення гострої розшаровуючої аневризми аорти становить 2-9 випадків на 100 тис. населення на рік [11]. Найчастішими симптомами при гострій розшаровуючій аневризмі аорти є різкий, сильний біль у грудях чи спині [11]. Розшарування аорти типу А може виникати внаслідок хронічної гіпертензії, патології аорти, а також у пацієнтів з попереднім кардіохірургічним втручанням [2]. Гостра інтраопераційна, хронічна післяопераційна розшаровуюча аневризма і псевдоаневризма висхідної аорти спостерігаються відносно рідко, але є потенційно небезпечними ускладненнями після різних кардіохірургічних операцій [1]. Розшарування висхідної аорти $є$ небезпечним ускладненням, яке призводить до ле- тальних наслідків без хірургічного втручання у $50 \%$ пацієнтів у найближчі 48 годин [10].

Мета роботи.У роботі представлено складний випадок розшарування грудного та черевного відділів аорти типу А, помірної до вираженої аортальної недостатності в пацієнта 3 пароксизмальною формою фібриляції передсердь, гіпертонічною хворобою та ожирінням 4-го ступеня після проведеного аортокоронарного шунтування (АКШ) та тромбектомії клубово-підколінного сегмента праворуч.

Матеріали і методи. Пацієнт віком 39 років, з масою тіла 163 кг поступив у відділення зі скаргами на підвищення артеріального тиску, біль у правій нижній кінцівці та порушення ії функції. Скарг на біль за грудиною не було. Після проведеного АКШ-3 off-pump у 2015 році впродовж 3 років відзначав епізодичні підвищення артеріального тиску до 210-120 мм рт. ст., а вже в січні 2019 року - різке підвищення артеріального тиску до 240-180 мм рт. ст. та різкий біль у правій ниж- 
Рисунок 1. КТ-ангіограма з внутрішньовенним контрастуванням. Білими стрілками позначено хід диссекціі в аорті

Рисунок 2. КТ-ангіограма з внутрішньовенним контрастуванням. Білою стрілкою позначено початок диссекції на висхідній аорті
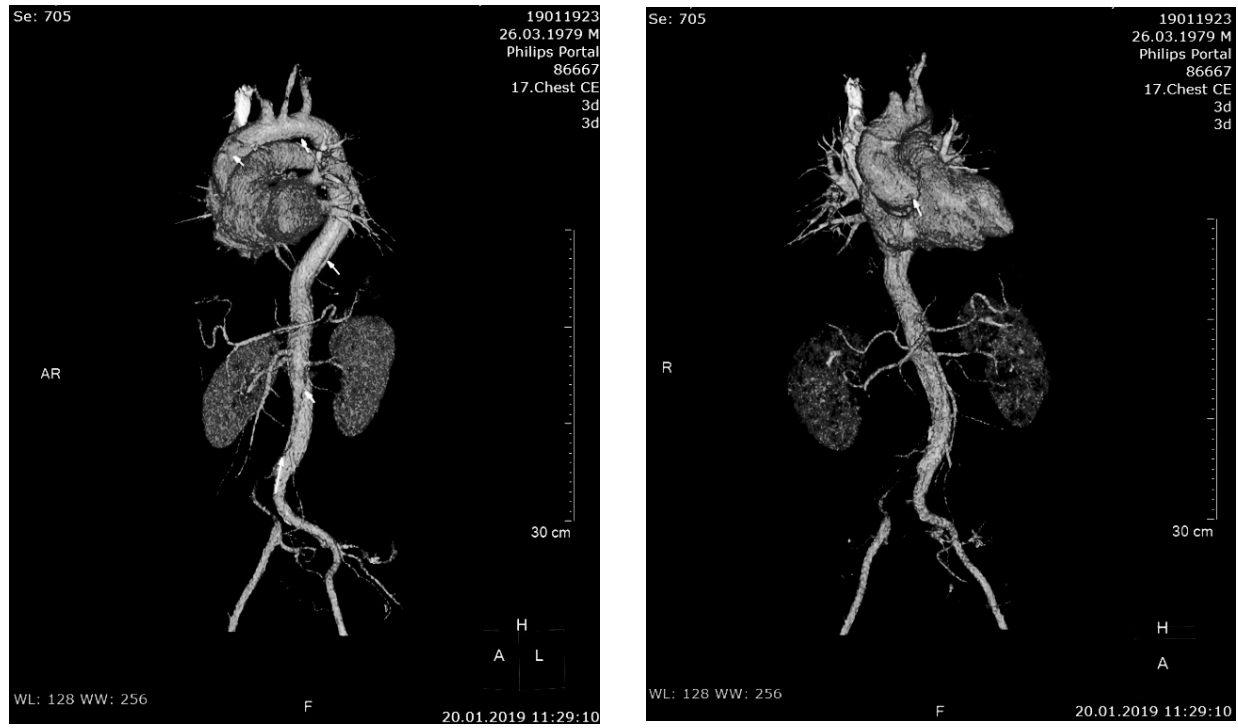

ній кінцівці. Пацієнта було госпіталізовано та проведено ультразвукове дослідження (УЗД) судин нижніх кінцівок, діагностовано тромбоз стегново-підколінного сегмента праворуч та проведено тромбектомію клубово-підколінного сегмента в ургентному порядку. Після оперативного втручання зберігались зниження чутливості, субкомпенсована гемодинаміка нижньої кінцівки, що вказувало на збереження ішемії кінцівки. Тому вирішено провести КТ-ангіографію черевного відділу аорти з внутрішньовенним контрастуванням, на якій відзначено розшарування аорти. Далі виконано КТ-ангіографію 3 внутрішньовенним контрастуванням грудного відділу. Було діагностовано розшарування грудного та черевного відділів аорти DeBakey I типу, Stanford A (рисунок 1, 2).

Артеріальний тиск був на рівні 150-100 мм рт. ст. За даними ехокардіографії, діаметр кільця аортального клапана становив 30 мм, діаметр на рівні синусів Вальсальви - 43 мм, помірна до вираженої аортальна недостатність (P 1/2 time(mc) 172), кінцевий діастолічний об'єм лівого шлуночка - 147 мл, розмір лівого передсердя - 53 мм, незначна мітральна недостатність, розміри міжшлуночкової перегородки та задньої стінки лівого шлуночка в діастолу - по 14 мм. Пацієнту проведено також УЗД нирок, яке виявило ознаки мікролітіазу та відсутність кровотоку в правій нирковій артерії. На підставі отриманих даних прийнято рішення про оперативне втручання з приводу розшаровуючої аневризми аорти та недостатності аортального клапана. В операційній проведено черезстравохідну ехокардіографію (ЕхоКГ): виявлено надрив інтими (початок диссекціï) на рівні синусів Вальсальви, виражену аортальну недостатність, невелику мітральну недостатність, у низхідній аорті візуалізувався істинний та хибний просвіти з тромботичними масами (періаортально). До початку стернотомії виділена стегнова артерія. Технічні труднощі створювала надмірна маса пацієнта (вага 163 кг, індекс маси тіла 54,5 кг/м²). Після виконання серединної стернотомії та кардіолізу візуалізовано синюшного кольору проксимальну частину висхідної аорти (до 3,8-4 см за даними ЕхоКГ). Мобілізовано та взято на затискачі 2 венозні графти до системи правої та огинаючої коронарних артерій - вони добре пульсували (рисунок 3). Мобілізовано ліву внутрішню грудну артерію, яка анастомозована з передньою міжшлуночковою артерією.

Підключено апарат штучного кровообігу. Аорту канюльовано технікою Сельдінгера, одразу проксимальніше від місця відходження плечоголовного стовбура. Істинний просвіт було визначено за допомогою черезстравохідної ЕхоКГ. Канюляція порожнистих вен типова. Гіпотермія - до $23^{\circ} \mathrm{C}$. Розчин холодової кров’яної кардіоплегії подано ретроградно в коронарний синус,

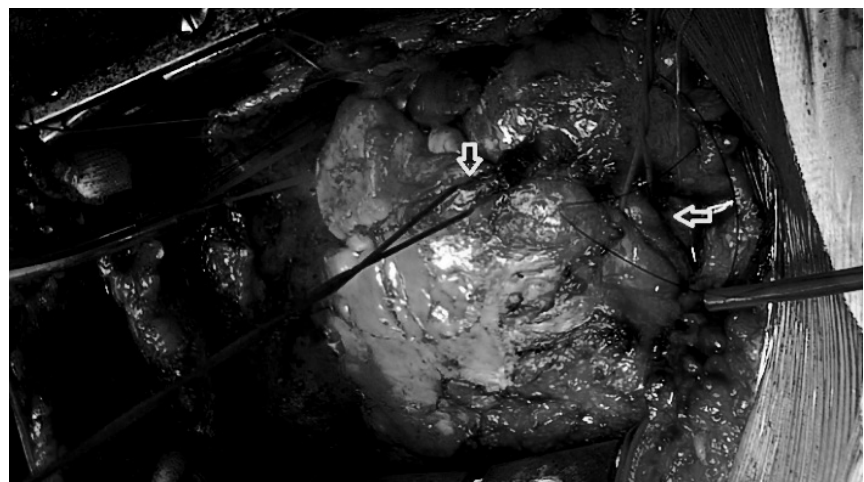

Рисунок 3. Виконано кардіоліз. Жовтими стрілками позначено виділені шунти 


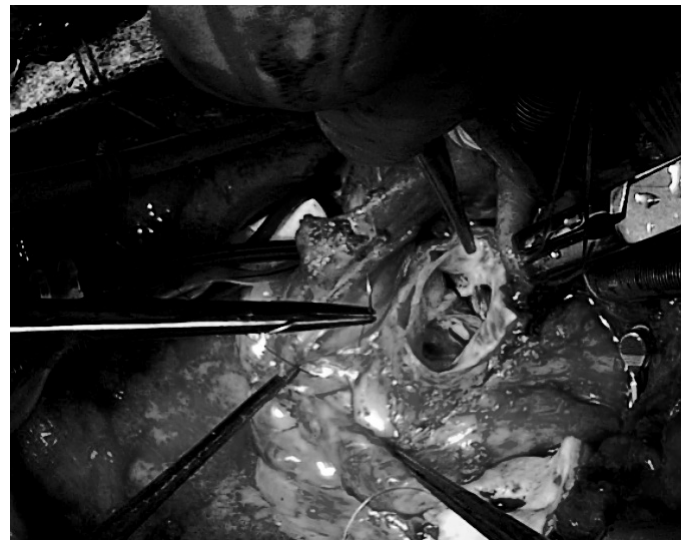

Рисунок 4. Аортальний клапан з видимою диссекцією стінки кореня аорти

а після поперечної аортотомії через аневризму - почергово у вічка коронарних артерій та венозні графти. Під час ревізії візуалізовано розшарування стінки аорти, яке починалося з некоронарного синуса та продовжувалося на висхідну аорту по ії дорсальній поверхні. Виявлено також відшарування комісури між правою та некоронарною стулками клапана аорти, що спричиняло виражену аортальну недостатність. Аортальний клапан тристулковий, стулки інтактні (рисунок 4). Виконано ресуспензію розшарованої частини кореня аорти та аортального клапана обвивним безперервним швом (рисунок 5).

Від розшарованої висхідної аорти мобілізовано та відсічено венозні графти на окремих пеньках (button). Біля проксимального анастомозу венозного графта, що кровопостачає праву коронарну артерію візуалізовано розшарування (рисунок 7). Накладено проксимальний анастомоз обвивним безперервним швом су-

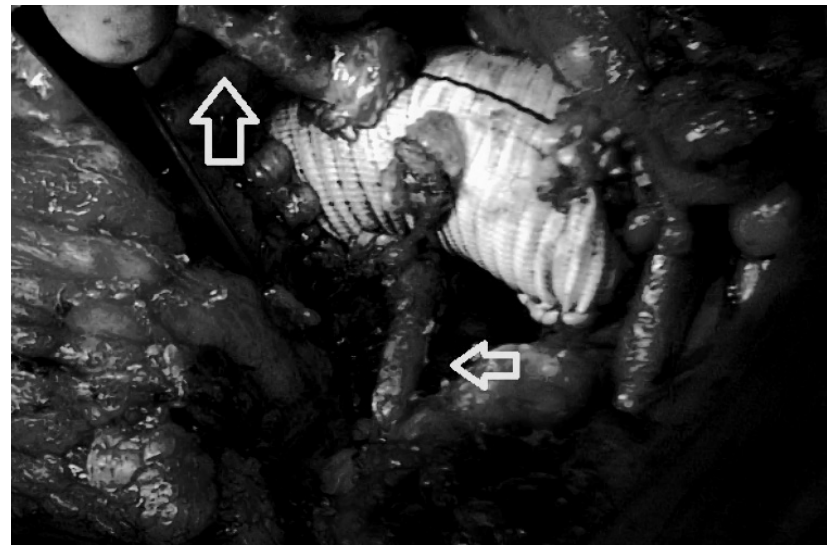

Рисунок 6. Виконано протезування висхідної аорти та реімплантацію венозних графтів (позначено жовтими стрілками)

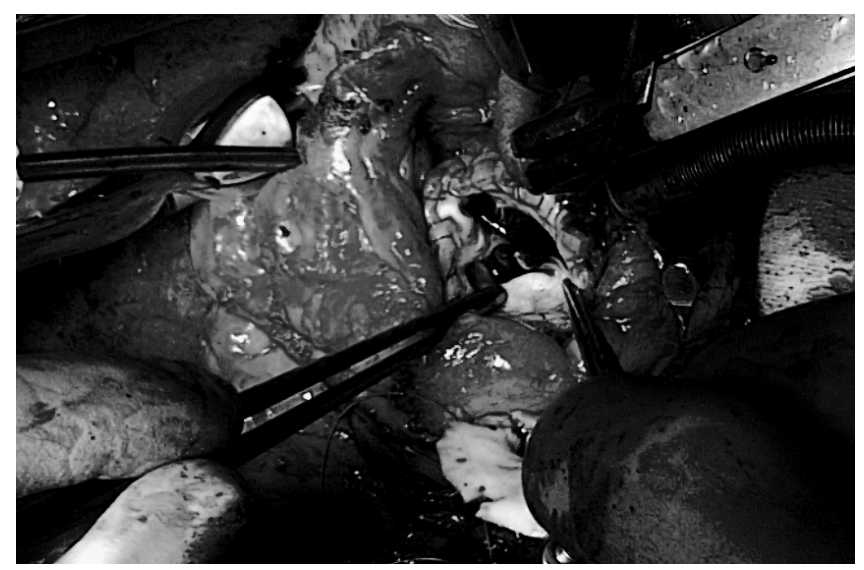

Рисунок 5. Виконано ресуспензію аортального клапана

динного протеза (Vascutek 30 мм) з аортою вище вічок коронарних артерій на 0,6-0,8 см. Накладено анастомоз кінець-у-бік обвивним безперервним швом між венозним графтом і судинним протезом (button technique), дефект біля венозного графта на праву коронарну артерію взято в шов. Відзначено зупинку кровообігу. Розпочато ретроградну перфузію головного мозку через верхню порожнисту вену. Перфузія головного мозку контролювалась за допомогою церебральної оксиметрії, яка перебувала в межах $67-72 \%$, а також за допомогою центрального венозного тиску, який тримався в межах 30-35 мм рт. ст. Під час ревізії було виявлено, що розшарування продовжується на дугу та низхідну частину аорти. Стінка дуги звичайного вигляду, товста, міцна, діаметром до 2,8-3 см. Висічена мала кривизна дуги аорти до рівня лівої підключичної артерії (Hemiarch) і виконано ресуспензію розшарованих тканин дуги аорти. Накладе-

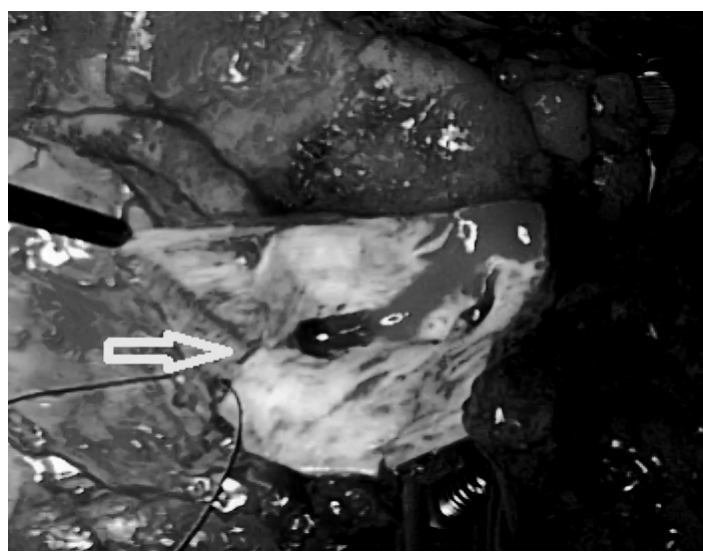

Рисунок 7. Проксимальні анастомози венозних графтів із диссекцією біля вени на праву коронарну артерію 
но дистальний анастомоз кінець-у-кінець обвивним безперервним швом судинного графту та дуги аорти (рисунок 6). Аортальну канюлю вставлено в протез висхідної аорти, відновлено штучний кровообіг. Проведено зігрівання і профілактику повітряної емболії. Знято затискач з аорти. Відновлено синусовий ритм через дефібриляцію.

Тривалість штучного кровообігу становила 264 хв, затиснення аорти - 137 хв, ретроградної перфузії у верхню порожнисту вену - 34 хв. Хворий екстубований через 65 годин після операції. У найближчі 13 годин після екстубації пацієнт потребував неінвазивної вентиляції легень з безперервним позитивним тиском у зв'язку з підвищенням рСО, до 50,2 мм рт. ст. Через 40 годин після виїзду з операційної виникло різке зменшення діурезу. При проведенні УЗД органів черевної порожнини виявили відсутність кровотоку у правій нирковій артерії, що відходила від несправжнього просвіту. Через значне зменшенням діурезу та підвищення креатиніну було проведено два сеанси гемодіалізу, після яких діурез відновився. У пацієнта також наростали симптоми ішемії правої нижньої кінцівки. Були скарги на постійний ниючий біль, блідий колір шкіри, набряк та зменшення температури правої нижньої кінцівки. Діагностовано тромбоз артерії в клубово-стегновому сегменті правої ноги згідно з даними КТ та клінічної картини (див. рисунок 1,2$)$. Під час ревізії права поверхнева стегнова артерія мала діаметр 8 мм і не пульсувала, ліва стегнова артерія діаметром 10 мм, пульсувала, прохідна. Пацієнту виконано стегново-стегнове шунтування між лівою стегновою артерією та правою поверхневою стегновою артерією конусним армованим протезом IMPRAePTFE 8-5 мм. Анастомози сформовані за типом кінець-у-бік. Шунт проведено надлобково. 3'явилася пульсація артерії нижче анастомозу. Після операції права нижня кінцівка задовільної температури та кольору, відновлено активні й пасивні рухи в повному об'ємі, відзначається біль у зоні післяопераційних рубців. Пацієнта виписано в задовільному стані на амбулаторне спостереження.

Результати та обговорення. Симптоми виникнення гострого розшарування аорти детально описані в літературі. Розшаровуюча аневризма аорти є рідкісним ускладненням після попередньо проведеного кардіохірургічного втручання. Факторами ризику розшарувань аорти є: артеріальна гіпертензія, двостулковий клапан аорти й коарктація аорти, обтяжений сімейний анамнез щодо хвороб аорти, генетично детерміновані захворювання сполучної тканини, кістозний аортит, травми, гемодинамічні та гормональні чинники під час вагітності, синдром Тернера, стан після кардіохірургічної операції. У 27 \% пацієнтів розшаровуючу аневризму типу А діагностують після гіпертонічного кризу, аортальна недостатність наявна у 44 \%, лише
10 \% пацієнтів не відчувають болю в грудях під час розшарування [11].

Ми вважаємо, що розшарування аорти в цього пацієнта виникло внаслідок комбінації двох факторів: артеріальної гіпертензії та попередньої кардіохірургічної операції, оскільки симптоми ішемії правої нижньої кінцівки розпочались після гіпертонічного кризу, а також початок диссекції в характерному для накладеного затискача місці. У середньому інтервал між проведеним АКШ і зверненням пацієнтів з віддаленою диссекцією аорти типу А - 40-52,9 місяця [1, 2]. За даними літератури їі частота становить $0,06 \%$ [4]. Гострі ятрогенні диссекції під час кардіохірургічних операцій можна розпізнати наочно чи пропальпувавши аорту безпосередньо в операційній або за симптомами мальперфузії, що виникають одразу після підключення апарата штучного кровообігу. Пацієнти з ожирінням не мають більшого ризику смерті або інших несприятливих наслідків після хірургічної корекції розшаровуючої аневризми аорти типу А. Тому хірургічний підхід слід розглядати в усіх пацієнтів 3 розшаровуючою аневризмою типу А, незалежно від їхньої ваги [8]. Мальперфузія є поширеною проблемою в пацієнтів із гострою розшаровуючою аневризмою аорти, зафіксованою мальперфузією нижньої кінцівки у 15 \% хворих. Зазвичай мальперфузія зникає після корекції аневризми аорти в результаті декомпресії несправжнього просвіту [9]. Диссекцію аорти як ятрогенне ускладнення можна порівняно легко розпізнати у випадку, якщо короткий інтервал (тижні або місяці) між первинною операцією і виявленим розшаруванням. Але в пацієнтів, у яких первинна операція була кількома роками раніше, важко бути впевненим, що розшарування є ятрогенним [1]. У нашому випадку в пацієнта виявлено початок диссекції 3 некоронарного синуса, а також має місце відшарування комісури між правою та некоронарною стулками, що спричиняло наявність вираженої аортальної недостатності. За даними літератури, розрив інтими, що зумовлює розшарування аорти після проведеного АКШ, найчастіше розміщений у місці накладання бокового затискача на аорту [1]. Під час накладання дистального анастомозу аорти за типом Hemiarch ми використовували циркуляторний арешт з ретроградною перфузією головного мозку та глибокою гіпотермією, оскільки саме цей метод дає достатньо часу (до 50 хв) для накладання анастомозу [3]. Також цей метод дозволяє краще візуалізувати операційне поле з потенційно низьким ризиком емболічних випадків [3]. Після застосування методу в пацієнта не було виявлено жодних неврологічних порушень, що підтверджує безпеку в його проведенні. У пацієнта виникли симптоми гострої ниркової недостатності. Частота таких ускладнень не є рідкістю і сягає 18-55 \% [5]. Тяжкість гострої ниркової недостатності сильно впливає на ви- 
дужання пацієнтів, тому слід негайно розпізнавати та агресивно лікувати таке ускладнення [5, 7]. Необхідно звертати більшу увагу на запобігання виникненню гострої ниркової недостатності в пацієнтів з ожирінням [7]. За даними деяких авторів, гостра ниркова недостатність у пацієнтів з ожирінням виникає частіше. Наш пацієнт скаржився тільки на гострий, різкий, постійний біль у правій нижній кінцівці, а біль у грудях заперечував. $Є$ дані, що в пацієнтів з розшаруванням типу А та ішемією нижніх кінцівок частіше спостерігаються симптоми болю в спині, животі та ногах, ніж у грудях [6].

\section{Висновки}

- Пацієнти після кардіохірургічних втручань у віддалений період, особливо після аортокоронарного шунтування, з розшаруванням аорти входять до групи найбільшого ризику [2].

- Використання ретроградної церебральної перфузії під час циркуляторного арешту та глибокої гіпотермії є безпечним методом для проведення операції з формуванням дистального анастомозу аорти за типом Hemiarch.

- Симптоми гострого розшарування аорти типу А після кардіохірургічних операцій у віддалений період можуть відрізнятися від класичних симптомів.

\section{Список використаних джерел References}

1. Hagl C, Ergin MA, Galla JD, Spielvogel D, Lansman S, Squitieri RP, et al. Delayed Chronic Type A Dissection Following CABG: Implications for Evolving Techniques of Revascularization. Journal of Cardiac Surgery. 2000;15(5):362-7.

2. Gillinov AM, Lytle BW, Kaplon RJ, Casselman FP, Blackstone EH, Cosgrove DM. Dissection of the ascending aorta after previous cardiac surgery: Differences in presentation and management. The Journal of Thoracic and Cardiovascular Surgery. 1999;117(2):252-60.

3. Tanaka A, Estrera AL. Simple retrograde cerebral perfusion is as good as complex antegrade cerebral perfusion for hemiarch replacement. Journal of Visualized Surgery. 2018;4:50. https://doi.org/10.21037/jovs.2018.02.10

4. Özçına E, Çakıcı M, BaranÇ, Gümüş F, ÖzgürA, Yazıcıoğlu L, et al. Results of late-onset type A aortic dissection after previous cardiac surgery: Does prior coronary artery bypass grafting affect survival? Turkish Journal of Thoracic and Cardiovascular Surgery. 2018;26(1):1-7. https://doi. org/10.5606/tgkdc.dergisi.2018.14683

5. Ko T, Higashitani M, Sato A, Uemura Y, Norimatsu T, Mahara K, et al. Impact of Acute Kidney Injury on Early to Long-Term Outcomes in Patients Who Underwent Surgery for Type A Acute Aortic Dissection. The American Journal of Cardiology. 2015;116(3):463-8. https://doi. org/10.1016/j.amjcard.2015.04.043

6. Alaei S, Sundt TM, Sechtem U, Myrmel T, Di Eusanio M, Gleason T, et al. A 15-year Analysis and Descriptive Study of the Incidence, Clinical Characteristics, Management, and Outcomes of Lower Limb Ischemia in Type A and Type B Aortic Dissection Patients: Insights From the International Registry of Acute Aortic Dissection. Circulation. 2015;132:A20003.

7. Zhao H, Pan X, Gong Z, Zheng J, Liu Y, Zhu J, et al. Risk factors for acute kidney injury in overweight patients with acute type A aortic dissection: a retrospective study. Journal of Thoracic Disease. 2015;7(8):1385-90. https:// doi.org/10.3978/j.issn.2072-1439.2015.07.19

8. Kreibich M, Rylski B, Bavaria JE, Branchetti E, Dohle D, Moeller P, et al. Outcome after Surgery for Aortic Dissection Type A in Morbidly Obese Patients. The Annals of Thoracic Surgery. 2018;106(2): 491-7. https://doi. org/10.1016/j.athoracsur.2018.03.035

9. Gottardi R, Resetar M, Bacher B, Freilibs E, Taheri N, Steindl J, et al. Concomitant Femoro-Femoral Bypass Graft During Surgery for Acute Type A Dissection to Treat Lower Limb Malperfusion. The Annals of Thoracic Surgery. 2015;99(1):307-9. https://doi.org/10.1016/j. athoracsur.2014.02.072

10. Crawford ES. The diagnosis and management of aortic dissection. JAMA. 1990;264:2537-41.

11. Golledge J, Eagle KA. Acute aortic dissection. Lancet. 2008;372:55-66. 6736(08)60994-0

\title{
Prosthetic Repair of the Ascending Aorta in a Patient with Aortic Dissection Type A after Coronary Artery Bypass Grafting (Case Report)
}

\author{
Pavlenko A.V., Varbanets S.V, Dovgan O. M., Pukas O. Y.
}

\section{The Scientific-Practical Children's Cardiac Center The Ministry of Health Care of Ukraine, Kyiv, Ukraine}

\begin{abstract}
Aortic dissection after cardiac surgery is a rare abnormality in patients after prior coronary artery bypass grafting. This abnormality is often accompanied by aortic valve insufficiency, lower extremity malperfusion syndrome and other symptoms.

The aim. To represent a case of correction of aortic dissection type A, with moderate to severe aortic insufficiency and right lower limb malprofusion syndrome in a patient with overweight after previous cardiac surgery.

Materials and methods. A 39-year-old patient was hospitalized with complaints for increased blood pressure, pain of the right lower limb and it malfunction. During the examination, an aortic dissection type A was diagnosed, and the right lower limb malperfusion syndrome was diagnosed.
\end{abstract}


Results and discussion. Aortic dissection type A combined with aortic insufficiency and lower extremity malperfusion syndrome is a rare abnormality in overweight patients after the previous coronary artery bypass grafting carried out in 2015 . There were no descriptions of such cases in the local literature. Aortic prosthetic repair was performed with the formation of Hemiarch distal anastomosis using retrograde cerebral perfusion and femo-femoral shunting.

Conclusion. Prosthetic repair of the ascending aorta with the formation of Hemiarch distal anastomosis and resuspension of the aortic valve using retrograde cerebral perfusion and deep hypothermia, and formation of femo-femoral shunting provided good outcome in patient with aortic dissection, aortic valve insufficient, lower extremities malperfusion syndrome and overweight.

Keywords: aortic dissection type A, cardiac reintervention, femo-femoral bypass, prosthetic repair of the ascending aorta.

Стаття надійшла в редакцію 28.03.2019 р. 